Verena Perko

\title{
Migracije, družbeno angažirana muzejska tema, in zakaj se ji slovenski muzeji uspešno izogibajo?
}

Ključne besede: migracije, begunska kriza, muzeji, postmuzeji, muzeologija

DOI: $10.4312 /$ ars.10.2.136-148

Spominjanje je temelj pravičnosti. Pravičnost je tisto, kar spomine ohranja, ista pravičnost oblikuje prihodnost in izreka imperativ o dolžnosti spominjanja (P. Ricœur).

Begunska kriza se je v zadnjem letu dni (2015-2016) pred našimi očmi spremenila v človeško tragedijo, ki po mnogočem, ne le zaradi bodeče žice in neskončnih kolon obupanih ljudi na eni ter v strahu otrplih na drugi strani, spominja na čas druge svetovne vojne. Sredozemsko morje, opevani mare nostrum, je postalo grozljiva skupna grobnica brezštevilnih. Posledica vojne pa so tudi uničevanja zgodovinskih mestnih središč, spomenikov in druge kulturne dediščine na t. i. kriznih območjih, ki so dosegla nedoumljive razsežnosti. Škode ni mogoče oceniti, saj narašča s slehernim dnem: Mari, Dura Europos, Palmira in Apamea so nepopravljivo uničene. Vrhunec je bil dosežen lanskega avgusta z nepredstavljivo kruto usmrtitvijo Khaleda el Assada, osemdesetletnega nestorja sirske arheologije in direktorja arheoloških raziskav $\mathrm{v}$ Palmiri. Po večtedenskem mučenju so vodilnega dediščinskega strokovnjaka javno usmrtili sredi Palmire. Grozovito kaznovanje si je prislužil s trdovratnim molkom o skritih zakladih kulturne dediščine. Na tragični dogodek se je odzval ves kulturni svet. Italijanski minister za kulturo Dario Franceschini je dal v znak žalovanja in protesta izobesiti črne zastave po vsej Italiji. Mediji, posebej tisti, ki se ukvarjajo z zgodovino in kulturno dediščino, so posvetili številne prispevke in tematske številke uničevanju dediščine ter možnostim obnove uničenih spomenikov. ${ }^{1}$ Muzeji po svetu so se odzvali z razstavami, konferencami, predavanji, srečanji beguncev itd. Cilj je bil sodobno družbo pozvati k razmisleku in odprtemu dialogu, in sicer $z$ namenom ublažiti šok in strah pred neznanim ter zmanjšati plimo sovraštva, preden doseže vseuničujočo razsežnost. $Z$ begunsko krizo se je meddružbeni dialog pokazal kot nuja in ultimativni imperativ, kot nekaj, brez česar družbe prihodnosti ni več mogoče zagotoviti.

1 Tako je na primer Siriji in njenim izgubljenim kulturnim zakladom posvečena junijska številka italijanske revije Storica National Geographic (Milano, 2016). 
Ob usmrtitvi Khaleda sem kot aktivna članica slovenski odbor ICOM-a in ICOMOS-a pozvala, ${ }^{2}$ da izoblikujemo skupno protestno izjavo in jo posredujemo javnosti, vendar odziva ni bilo. Ob še nadaljnjem jesenskem zaostrovanju begunske krize, nepričakovani odločitvi za postavitev bodeče žice ob mejah in nerazumni poplavi demagoških objav v slovenskih medijih $^{3}$ je bilo samo po sebi umevno, da se oglasijo tudi muzeji in skušajo na podlagi kulturne dediščine po svoje prispevati $\mathrm{k}$ bolj demokratičnemu in kulturnemu javnemu diskurzu. ${ }^{4}$ Tako se je na primer Slovenski etnografski muzej oglasil kot "poklican k spoznavanju in razumevanju dogajanj $\mathrm{v}$ naši družbi, $\mathrm{k}$ ponovnemu razmisleku o razmerju med univerzalno človeškostjo in kulturno raznolikostjo in vprašanju, kaj nas bolj druži kot loči«. ${ }^{5}$

Primanjkljaj slovenske družbe na področju vzpostavljanja odprtega družbenega dialoga in oblikovanja javnih forumov, kjer bi bilo mogoče v dobro vseh izmenjavati diametralno različna mnenja ter seveda tudi javno obsoditi nesprejemljiva in na ta način soustvarjati pravičnejšo družbo, je postal boleče očiten. ${ }^{6}$ Muzej narodne osvoboditve Maribor se je na dogodke odzval s fotografsko razstavo in pedagoškimi delavnicami, s katerimi je želel spremeniti s stereotipi prežeto, beguncem sovražno okolje. V programu Muzej za mir so obravnavali problematiko kratenja človekovih pravic ter opozarjali mlade na potrebo po kritično oblikovanih mnenjih in strpnih reakcijah na izzive iz okolja. Slovenski etnografski muzej je v sodelovanju $\mathrm{z}$ drugimi institucijami in nevladno organizacijo Slovenska filantropija organiziral terensko delo med begunci v begunskem centru Šentilj ter v največjem evropskem begunskem centru Idomeni na grško-makedonski meji. Pripravil je štiri razstave na temo beguncev in migrantov. V Muzeju novejše zgodovine Slovenije so med drugim pripravili priložnostno gostujočo razstavo o beguncih. Ostali slovenski muzeji pa so svojo pozornost - ter s tem pozornost obiskovalcev in širše javnosti - usmerjali na nevtralne muzejske teme. Razstavljali so umetnine, knjige, arhivske dokumente,

2 ICOM je neprofitna nevladna organizacija, ki povezuje muzeje in muzealce po vsem svetu. Ima več kot 30.000 članov iz 137 držav. Ustanovljen je bil leta 1947 pri UNESCU. Slovenija je bila do leta 1991 članica jugoslovanskega ICOM-a, od takrat dalje pa deluje samostojno. ICOMOS je sorodna mednarodna organizacija, ki deluje s podobnimi cilji na področju nepremične dediščine.

$3 \mathrm{~V}$ mislih imam objave in javne komentarje o nekulturi pribežnikov in o Siriji ali celo celotnem Bližnjem vzhodu kot deželi brez kulture.

4 Za informacije se zahvaljujem mag. Ralfu Čeplaku Mencinu.

5 Ralf Čeplak, BEGUNCI SO TU! Prizadevanja Slovenskega etnografskega muzeja proti stereotipom, predsodkom in ksenofobiji. Prispevek na 1. mednarodnem kongresu slovenskih muzealcev, Piran, 20.-22. 10. 2016.

6 V Muzeju novejše zgodovine Slovenije so gostujočo razstavo o beguncih (16. 2.-22. 3. 2016) pospremili s temi besedami: „Če danes besedo begunec spremlja negativen prizvok, pa bi se bilo dobro spomniti na slovenske begunce v Avstriji, ki so po letu 1945 pisali zgodbo o izjemni organizaciji in močni narodni zavesti.« Vir: http://www.rtvslo.si/kultura/razstave/razmisleko-slovenskih-begunskih-zgodbah/385933 [15. 10. 2016]. Na to temo je izšla tudi fotografska monografija Cvetoči klas pelina z več kot 300 fotografijami in obširno zgodovinsko študijo. 
čipke in arheološke predmete ter se posvečali temam, kot je na primer belo zlato in zlata vredna mala črna. ${ }^{7}$ Sodobni slovenski družbi niso posredovali opaznejšega relevantnega sporočila, ki bi ljudem omogočilo begunce dojeti kot žrtve vojne in ne le v luči strahu in splošne panike. Slovenskim davkoplačevalcem se zato utegne zgoditi, da bodo prej kot $\mathrm{v}$ naših muzejih begunca srečali na preživljanju dopusta - $\mathrm{v}$ morju.

Namen pričujočega prispevka je pojasniti družbeno vlogo sodobnih muzejev kot instrumenta demokratizacije in poskusiti najti odgovor na vprašanje, zakaj so se slovenski muzeji, razen nekaj izjem, tako medlo odzvali na begunsko krizo in komu ustreza njihova pasivna družbena vloga.

\section{O družbeni vlogi sodobnih muzejev}

Drugo polovico 20. stoletja je zaznamovala postmoderna doba. Ena od njenih značilnosti je hiter razvoj humanističnih ved, ki je med drugim omogočil prepoznavanje družbenega pomena dediščine (Smith, 2006). Sledeč potrebam družbe in novim spoznanjem, se je na področju dediščinske teorije zgodil pomik $\mathrm{k}$ holističnemu konceptu, ${ }^{8}$ ki sta mu sledila povezovanje dediščinskih ustanov in razvoj muzejev v smer medijev (Šola, 2003). Spoznanje, da je prepoznavanje aktualnih družbenih stanj mogoče doseči s pomočjo analize in interpretacije preteklih zgodovinskih dob ter družbeno-političnih procesov, $\mathrm{v}$ smislu historia magistra, ni novo. Novo za muzeje pa je prevzemanje aktivne družbene vloge, pri čemer sta temeljnega pomena reflektirana dediščinska interpretacija in neverbalna, kontekstualna komunikacija, ki posredno ponuja uvid v aktualno družbeno dogajanje (Sandell, 1998; Maggi, 2005).

Zbirke in muzeji so imeli skozi vso zgodovino posebno družbeno vlogo, četudi ni bila zelo očitna in je bila bolj ali manj pasivne narave. Pomembnejša vloga jim je bila dodeljena v času francoske revolucije (Hudson, 1988, 4-7), bolj družbeno dejavni pa so postali ob koncu 19. in v prvi polovici 20. stoletja $\mathrm{z}$ aktivnim prevzemanjem izobraževalnih vlog. ${ }^{9}$ Ena najpomembnejših raziskovalk muzejev, Eilean Hooper-

7 Belo zlato in zlata vredna mala črna je bil »duhovit« naslov razstave izdelkov mladih oblikovalcev Tekstilne fakultete v Ljubljani v prostorih Narodnega muzeja Slovenije od 20. januarja do 6. marca 2016. Naslov odraža čedalje bolj prevladujočo tendenco, da bi muzeji postali tržno čim uspešnejši, zaradi česar je treba skrbeti za »zabavne in nezatežene« teme. Luca Caburlotto, vodja dediščinskih služb za Veneto in Furlanijo, je na 1. mednarodnem kongresu slovenskih muzealcev v Piranu (20.-22. 10. 2016) izpostavil misel, da je prva naloga sodobnih muzejev vzgoja za državljana.

8 Holistični koncept je razviden na primer iz konvencije Faro 2005, ki jo povzema tudi trenutno veljavni Zakon o varstvu kulturne dediščine v Sloveniji. Vir: http://www.coe.int/t/dg4/cultureheritage/ heritage/Identities/default_en.asp [20.7.2016].

9 Primer enega prvih muzejev $\mathrm{z}$ arheološkimi zbirkami v primarno izobraževalne namene je muzej 
Greenhill, je s pomočjo Foucaultovega filozofskega dela ${ }^{10} \mathrm{o}$ pojmu episteme pojasnila družbene vloge muzejev skozi čas in pokazala na njihovo dialektiko (HooperGreenhill, 1999, 1-22). Osvetlila je njihovo odvisnost od vsakokratnega družbenopolitičnega in ekonomskega ustroja družbe. Po Hooper-Greenhillovi med sodobnimi muzeji prepoznavamo modernistične in postmuzeje (Hooper-Greenhill, 2000, 125-150). Za prve veljajo značilnosti muzejev kot raziskovalnih, statičnih ustanov 19. stoletja, osrediščenih v skrbi za svoje zbirke. Namenjajo jim vso raziskovalno, konservatorsko, publicistično in izobraževalno pozornost, razstave in druge muzejske dejavnosti sledijo raziskovalnim interesom posamezne znanstvene veje, neredko celo interesom posameznih raziskovalcev. Javnosti namenjajo obrobno pozornost, komunikacija je običajno omejena na seznanjanje $\mathrm{z}$ muzejskimi dejavnostmi in obveščanje o rezultatih posameznih raziskav. Postmuzeje pa opredeljuje usmerjenost $\mathrm{v}$ služenje javnosti. Prepoznamo jih po nenehnih raziskavah javnosti in dobrem poznavanju potreb sodobne družbe, rezultate upoštevajo $\mathrm{z}$ namenom izboljšanja komunikacije v danem kulturno-družbenem okolju. Tomislav Šola postmuzeje prepoznava kot predstavnike tretjega muzejskega, tj. komunikacijskega vala. ${ }^{11}$ Sodijo $\mathrm{v}$ družino medijev javnega obveščanja, od drugih jih razlikuje specifična muzejska komunikacija (Mairesse, 2010, 41-58).

Reformatorji muzejev druge polovice 20. stoletja so izhajali s stališča, da tradicionalni muzeji kljub reorganizacijam ne morejo $\mathrm{v}$ celoti streči potrebam in zahtevam sodobne demokratične družbe (Šola, 2003, 33). To je pospešilo oblikovanje novih teoretskih podlag, t. i. nove muzeologije, ki muzej prepoznava kot družbeno odgovorno ustanovo, povezano z okoljem (Scheiner, 2010). Nova muzeologija obsega teoretske podlage, ki omogočajo razumeti ustroj sodobne družbe in opremljajo $\mathrm{s}$ specifičnimi muzeološkimi znanji o dediščinski komunikaciji neverbalnega, neredko celo subliminalnega značaja (Šola, 2010; Maroević, 2010).

Ožje področje muzeološkega raziskovanja so vprašanja identificiranja muzealnosti ali vprašanja, ki se nanašajo na odločitev, kateri predmet bo shranjen v muzeju, ali bo tudi razstavljen in na kakšen način bo interpretiran (Maroević, 1997). Odločitve so neločljivo povezane s kulturnimi vrednotami in politično usmerjenostjo določenega družbenega miljeja. Teoretično pa so to vprašanja slojevitosti dokumenta in informacij, zakodiranih v muzejskem predmetu. Muzeologija raziskuje prenos informacij med preteklostjo in sedanjostjo, med razvitim in manj razvitim svetom, med različnimi

generala Pitta Riversa (Pitt Rivers Museum) na Univerzi v Oxfordu (Hudson, 1988, 31).

10 Michel Foucault, Les mots et les choses: Une archéologie des sciences humaines (1966). V slovenskem prevodu: Besede in reči

11 Tomislav Šola prepoznava tri muzejske valove, to so: protomuzejski, informativni in komunikacijski val (Šola, 2003, 56). 
družbenimi razredi in statusi - kar so temeljne značilnosti in družbene naloge muzejske komunikacije (Maroević, 1999).

Muzejska komunikacija poteka s pomočjo dediščinskih predmetov in vsebin $\mathrm{v}$ skladu z njihovo muzealnostjo, ne da bi se ob tem spremenil njihov dokumentarni značaj. Muzejski predmet $\mathrm{v}$ procesu prenosa sporočil ali semioze nadgrajuje svojo primarno vlogo, vlogo, ki jo ima $\mathrm{v}$ muzeju kot dokument izvirnega dediščinskega konteksta: v razstavnih kontekstih prevzema simbolne in metonimične vloge, ki vzpodbujajo asociativne miselne povezave in poustvarjajo nove pomene (Maroević, 2002). Na ta način izvabimo narativno moč muzejskega predmeta ter pri publiki izzovemo sublimne čustvene vezi in ustvarjamo nove asociativne povezave med vsebinsko sicer nepovezanimi pojavi in jim damo nov smiselni pomen. Pomene, ki jih ustvarimo s pomočjo kontekstualiziranega predmeta iz preteklih dob, obiskovalec doživlja v sklopu svojih lastnih življenjskih izkušenj. Ni nujno, da asociativni proces steče v času ogleda razstave ali obiska muzeja, lahko se sproži ob podobni življenjski situaciji veliko kasneje. Človek doživlja čas povezano, v nepretrganem časovnem loku spominov, ne nujno sledečih si v kronološko objektivnem časovnem zaporedju. To omogoča, da ponotranjene podobe preteklosti sooblikujejo njegovo doživljanje in mu omogočijo razumevanje situacij vsakdanjega življenja (Perko, 2014, 159).

Metonimija odpira neomejene možnosti muzejskega sporočanja in daje muzejskemu predmetu posebno družbeno avro. S pomočjo opredmetene govorice, interpretacije preteklih civilizacij ali posameznih kulturnih pojavov muzej omogoča vpogled v sodobnost in jo tudi kritično reflektira. Služi lahko kot ključ do razumevanja pojavov sodobne družbe in je zato lahko tudi izjemno učinkovito orodje manipulacije javnosti. Najbrž pa ni treba posebej poudariti, da se lahko vsaka muzejska dejavnost brez imperativa profesionalne etike iz orodja spoznanja in konstruktivne družbene kritike kaj hitro spremeni v prikrito politično orodje. Poglejmo primer: razstava, ki bi prikazovala rimski imperij z vidika »višje, razvite« rimske kulture in bi v kontekstu premagana ljudstva prikazovala kot manjvredne barbare, bi javnosti posredovala jasno neverbalno (imperialistično) sporočilo o barbarskosti (vseh koloniziranih) manj razvitih ljudstev. In še več. Metonimični proces omogoča tudi hkraten prenos sklopov vrednostnih pomenov, tako da na primer javnost vse sodobne imperije posledično povezuje s (plemenitim) širjenjem kulture in omogočanjem razvoja, nezahodna ali celo neevropska ljudstva pa posledično doživlja kot zaostala in »barbarska«.

Muzejsko komunikacijo opredeljuje značaj zbirke, ki jo določen muzej hrani, in muzejske javnosti z zelo različnimi potrebami in preferencami. Temelj muzejske komunikacije je in ostaja avtentični muzejski predmet ali avtentična dediščinska vsebina, na primer nesnovna dediščina (Maroević, 1999). Velik pomen prispeva tudi 
avtentični muzejski prostor kot izvirni kulturni milje okolja, v katerem se reprezentirajo dediščinske vsebine. $\mathrm{V}$ duhu antičnih muzejev bi smeli sodobni muzejski prostor primerjati s templjem (vendar ne v elitističnem smislu): z zbirkami, s strokovnjaki, z muzejsko stavbo in svojim komunikacijskim okoljem muzej sprejema vlogo poroka kulturnih in etičnih vrednot ter s tem tudi družbene avtoritete (Desvalleés, 2010, 127).

Razumevanje pomenov in mogočne moči muzejske komunikacije pa ni zgolj stvar teoretične razprave, kot lahko pogosto slišimo, temveč se nanaša predvsem na družbeno vlogo muzeja. To so temeljna vprašanja sodobne muzeologije, ki je omogočila razvoj postmoderne muzejske paradigme $\mathrm{v}$ šestdesetih letih prejšnjega stoletja in jo označujemo kot novo muzeologijo.

Nova muzeologija je integralno družbeno gibanje za ohranjanje kvalitete življenja in človeških temeljnih vrednot $\mathrm{s}$ pomočjo totalnega pristopa $\mathrm{k}$ varovanju dediščine $\mathrm{v}$ izvirnem okolju. ${ }^{12}$ Prizadeva si za vključevanje dediščine kot vrednote življenja in za doseganje družbene kohezije, s ciljem izboljšati položaj spregledanega, odrinjenega posameznika ali skupine (Perko, 2014, 67; in tam citirana literatura).

Nova muzeologija se spoprijema z vsem tistim, čemur "stara « muzeologija in tradicionalni muzeji v sodobni družbi niso bili kos, ali bolje rečeno, česar si nikoli niso postavljali za cilje svojega delovanja. Nova muzeologija si v prvi vrsti zastavlja naloge s področja kulturno socialnih vprašanj. Zanimajo jo politične, okoljske in ekonomske teme. Skuša najti odgovore na iskanja sodobnega, odtujenega človeka. Odkriva življenjske vrednote in smisel bivanja. Razkriva mehanizme družbene kontrole in interpretacije, pomaga prepoznavati avtoriteto in avtentičnost $\mathrm{v}$ lastnem okolju (Scheiner, 2010). Vrednote, ki jih utemeljuje nova muzeologija, so zadnja desetletja postale temelj muzejske profesionalne etike. Na praktični ravni se to kaže kot usmerjenost muzejev v družbeno odgovorno komunikacijo, na vsebinski pa kot trdna vpetost v lastno kulturno okolje (Marstine, 2011).

Sodobna muzeologija je izrazito interdisciplinarna veda in se glede na zgodovinskodružbene razmere iz dežele $\mathrm{v}$ deželo razlikuje. ${ }^{13} \mathrm{Na}$ tem mestu želim opozoriti na upoštevanja vredno, toda vse prepogosto prezrto tradicijo vzhodnoevropskih muzeoloških šol. Med najzgodnejše prištevamo brnsko Katedro za muzeologijo v nekdanji Češkoslovaški, sledili sta ji dresdenska v nekdanji Vzhodni Nemčiji in

12 Temeljna misel prof. Tomislava Šole, ki jo je začel širiti že v osemdesetih letih prejšnjega stoletja in je danes vodilo mednarodnih dediščinskih deklaracij.

13 Zbyněk Z. Stránský je leta 1970 muzeologijo definiral kot disciplino, ki se teoretično ukvarja z dejavnostjo muzejev ter se deli na teoretski in praktični del, slednji se imenuje muzeografija. Ivo Maroević je muzeologijo opredelil kot vedo, ki se ukvarja s preučevanjem muzealnosti kulturne in naravne dediščine, $\mathrm{z}$ vprašanji delovanja in razvojev muzejev ter $\mathrm{z}$ odnosi med muzejsko teorijo in prakso (prim. naslednje opombe). 
zagrebška v nekdanji Jugoslaviji. ${ }^{14}$ Strokovnjaki, ki so delovali v teh šolah, npr. Zbyněk Z. Stránský, ${ }^{15}$ Vinoš Sofka, Ivo Maroević, ${ }^{16}$ Tomislav Šola, Friedrich Waidacher ${ }^{17}$ in Peter van Mensch, ${ }^{18}$ so močno vplivali na razvoj sodobne kritične in družbeno angažirane muzeologije.

V sedemdesetih letih je bila tudi Univerza v Ljubljani na najboljši poti, da se priključi temu gibanju ${ }^{19}$-, če bi le tedanji priznani profesor muzeologije Sergej Vrišer našel vrednega naslednika in če bi slovenska družba razumela pomen novih muzeoloških znanj za razvoj sodobne družbe in sprejela novo paradigmo družbeno aktivnih muzejev. Na prvem mestu pa bi bila to naloga muzealcev. Seveda ni mogoče trditi, da smo Slovenci muzeološko neuki. Marsikaj se je napaberkovalo in nakapljalo $\mathrm{v}$ zadnjih desetletjih, a treba je priznati, da to znanje večidel sodi $\mathrm{k}$ muzeografiji, kot je tudi res, da z nekaj naključno izbranimi gostujočimi predavanji ne moremo biti kos resnim teoretskim temam. Poudarek je pretežno na muzeografskem znanju, ki muzejem omogoča zbirati, ohranjati, varovati in razstavljati, kar slovenski muzeji večidel opravljajo na strokovno korektni ravni. Vendar pa so sodobni muzeji ali, po Šoli, muzeji tretjega vala oziroma postmuzeji po Hooper-Greenhillovi muzeji z aktivnimi družbenimi nalogami (Šola, 2010). Zahtevajo angažiranega, družbeno aktivnega muzealca, ki v polnem sodelovanju $\mathrm{z}$ javnostjo išče kvalitetnejše poti sodobne družbe. Hkrati je res, da angažiran način prinaša družbeno odgovornost in nevarnost "političnega zdrsa«. Temu nasprotno družbene sinekure omogočajo tradicionalno muzejsko zazrtje v zbirke, "znanstvena objektivnost« pa deklarirano "apolitičnost«. Resnici na ljubo pa prav sodobna heritološka teorija kaže, da nobena od paradigem ni nevtralna (Smith, 2006). Ustanove, ki se vzdržujejo z davkoplačevalskim denarjem, po pravilu niso in ne morejo

14 Leta 1922 je začela pod vodstvom Jaroslava Heferta delovati muzeološka katedra v Brnu, leta $1946 \mathrm{v}$ Zagrebu na filozofski fakulteti muzeologijo uvedejo kot samostojni predmet, leta 1956 pa v Leipzigu odprejo Fachschule für Museologen in v Vzhodnem Berlinu Zentralle Fachstelle für Museen. Leta 1966 Zagreb dobi podiplomski študij muzeologije, 1984 pa odprejo zagrebško univerzitetno katedro za muzeologijo pri Informacijskih znanostih, katere vodja je postal profesor Ivo Maroević.

15 Stránský, Z., Pojam muzeologije. Muzeologija 8, 1970, str. 2-39.

16 Maroević, I., Uvod u Muzeologiju, Zagreb 1993.

17 Waidacher, F., Handbuch der allgemeinen Museologie, Wien, Köln, Weimar 1993; Waidacher, F., Muzeologija kao znanstvena disciplina i njezina primjena u svakodnevnom muzejskom radu, Informatica musologica 3-4, 1998, str. 81.

18 Mensch, P. van, Towards a methodology of museology. Doktorska disertacija, Zagreb 1992.

19 V študijskem letu 1971/72 je na Filozofski fakulteti v Ljubljani začel s predavanji iz muzeologije profesor Sergej Vrišer. V študijskem letu 1991/1992 se je predmet preimenoval v Muzeologija in konservatorstvo, vendar je bil omejen predvsem na muzeografske teme, program so izvajali do študijskega leta 1993/1994. Po tem letu je bil predmet ukinjen, predmet muzeologija pa se izvaja ločeno na Oddelku za umetnostno zgodovino ter Oddelku za etnologijo in kulturno antropologijo. Po uvedbi bolonjskega programa so se muzeološke in konservatorske teme na Oddelku za arheologijo združile pri predmetu Arheologija za javnosti, ki so mu prvi študenti tretjega letnika bolonjskega programa prisluhnili v študijskem letu 2011/2012, in pri predmetu Upravljanje z arheološko dediščino. 
biti politično nevtralne. Če se ne odzivajo na družbene dogodke in svojega delovanja ne aktualizirajo glede na potrebe sodobne družbe, dediščino »trgajo « iz kontekstov sodobnega življenja. S svojim početjem preprečujejo, da bi dediščina postala temeljni identitetni, izobraževalni, razvojno-gospodarski in politični kapital. Muzeji z umikanjem na bregove znanstvene nevtralnosti in politične korektnosti skupnosti »odtujujejo《 sodobna »orodja» demokratizacije in hromijo njen razvoj. Kulturna dediščina je temelj evropskosti, vendar le, če dediščinske ustanove svojo aktivno družbeno vlogo razumejo in udejanjajo na inkluziven in participativen način. ${ }^{20}$ Kot je razvidno iz zgodovinskega razvoja, pasivnost tradicionalnih muzejev $\mathrm{v}$ resnici pomeni politično mimikrijo, ki je $\mathrm{v}$ prvi vrsti v prid vsakokratni oblasti (Perko, 2014, 23-51).

Logičen zaključek bi torej bil, da kolikor bolj je oblast nedemokratična, toliko bolj podpira hromenje procesov demokratizacije ali, mutatis mutandis, toliko raje podpira njene ohromljene ustanove, vključno $\mathrm{z}$ muzeji. Glede na poti in stranpoti sodobne zahodne družbe je povsem razumljivo, da se na eni strani muzeologija močno "amerikanizira" $\mathrm{v}$ smislu tržnosti in muzeje tlači med zabaviščne parke. Na drugi strani neopazno tone v pozabo pomemben prispevek, ki so ga dale vzhodnoevropske in južnoameriške muzeološke šole $\mathrm{k}$ razvoju tej tržni usmeritvi nasprotne, družbeno angažirane muzeologije. Priča postajamo tudi dobro prikriti kulturni kolonizaciji, pri kateri aktivno sodelujejo tudi elitistično koncipirani muzeji bogatih zahodnih dežel. ${ }^{21}$ Medtem pa lahko $\mathrm{v}$ »deželah druge in tretje hitrosti« opazujemo uspešno spreminjanje muzejev v poslušna politična orodja in ne nepomemben vir okoriščanja $\mathrm{z}$ davkoplačevalskim denarjem (Hauptman, 2015). Posledično neslišno ugašanje malih kultur ne more biti veliko presenečenje (Evropa je bila pač vedno zgodba velikih). ${ }^{22}$

\section{Ko jagenjčki obmolknejo}

Slovenski muzejski strokovnjaki so intenzivno vključeni v mednarodna strokovna gibanja in aktivni člani mednarodnega združenja za muzeje ICOM pri UNESCU. Upam si trditi, da so dobro seznanjeni s temeljnimi sodobnimi muzejskimi trendi. Pa vendar se, z izjemo redkih, po letu in pol hude begunske krize, ki postaja človeška katastrofa z obeh strani begunske žice, večinoma niso odzvali na družbene potrebe po odprtem dialogu in kritični refleksiji migracij.

20 Resolucija Evropskega parlamenta $\mathrm{z}$ dne 8. septembra: Towards an integrated approach to cultural heritage for Europe, vir: http://www.europarl.europa.eu/sides/getDoc.do?pubRef=-//EP// TEXT+TA+P8-TA-2015-0293+0+DOC+XML+V0//EN [20. 7. 2016].

21 Bogati zahodnoevropski muzeji kar tekmujejo med seboj za ustanavljanje podružnic v arabskem svetu.

22 Poučen vpogled $\mathrm{v}$ preigravanja $\mathrm{z}$ dediščino ponuja študija Izidorja Janžekoviča o repatriaciji (Janžekovič, 2015). 
Toda zdi se, da tako stanje ustreza vsem: slovenski družbi, ki se ne želi soočiti s svojo pravo, glede na svojo predstavo o sebi močno malformirano podobo - in ki se je posebej izostrila $\mathrm{v}$ času begunske krize; politikom in državnim uradnikom, ki se lahko skrivajo za neuporabnimi, dvoumnimi in včasih celo protipravnimi predpisi; muzealcem, ki svojo muzejsko službo živijo na nespremenjen, tradicionalni, družbeno sinekurni način. Poleg družbene odgovornosti dediščinskih ustanov pa obstaja še osebna odgovornost. Intelektualna elita, še posebej strokovnjaki s področja dediščine in ohranjanja kolektivnega spomina, je dolžna reflektirati aktualne družbene pojave s stališča profesionalne etike (Sandell, 2011). Osebno pa smo vsi soodgovorni in dolžni opozarjati na posledice, o katerih se lahko dobro poučimo iz ne tako davne zgodovine. Med muzejskim gradivom je veliko zgodovinskega, etnološkega in umetnostnozgodovinskega gradiva ter tem o migracijah. Arheologija opazen del svojega raziskovanja tradicionalno namenja fenomenu migracij. Raziskuje vzroke in posledice ter njihov vpliv na razvoj posameznih kultur. Z raziskavami seže v čas prazgodovine. Indoevropske selitve so na primer že dolgo eno temeljnih vprašanj prazgodovinskih kultur in jezikov, na katera je arheologija prinesla odgovore s številnimi pomembnimi spoznanji. Propadu rimskega cesarstva in času tedanjih preseljevanj se intenzivno posvečata tako arheologija kot zgodovina. Slednja obravnava tudi begunce na čolnih, ki so Evropi ob padcu Bizanca leta 1453 prinesli ključna znanja za razvoj renesanse, italijanskim mestom pa obsežne knjižnice. Vendar govoriti o beguncih in begunski krizi pomeni posredno izpostavljati njihovo trpljenje ter pokazati na krivdo; pomeni vtikati prst v najgloblje in najsramotnejše rane Evrope; pomeni kazati na bodeče žice in koncentracijska taborišča, trpljenje in ponižanje, brezčutnost in ubijanje, sadizem in živalskost. Po Hannah Arendt bi to lahko pomenilo zazreti se sam vase.

Treba pa je upoštevati, da tradicionalno poslanstvo tradicionalnih, "pametnih" kulturnih ustanov ni v tem, da bi dražile spečega leva in si po nepotrebnem nakopale njegovo jezo. Njihova naloga je pisati dolge znanstvene razprave. Ali kot je imel navado svoja bleščeča predavanja zaključiti profesor Tomislav Šola: »Titanik se potaplja, mi pa skrbno poravnamo stole v vrsti.«

\section{Literatura}

Desvaleés, A., About the Definition of Museum, v: What is a museum? (ur. Davis, A., Mairesse, F., Desvaleés, A.), München 2010, str. 121-131.

Hauptman, H., »Muzej v vsako slovensko vas«. Varstvo kulturne dediščine na lokalni ravni, Argo 58/2, 2015, str. 20-35.

Hooper-Greenhill, E. (ur.), Museum, Media, Message, London, New York 1999. 
Hooper-Greenhill, E., Museums and interpretation of visual culture, London, New York 2000.

Hudson, K., Museums of Influence, Cambridge 1988.

Janžekovič, I., Elginova zbirka. Repatriacija in univerzalni muzeji, Argo 58/2, 2015, str. 36-57.

Maggi, M. (ur.), Museo e cittadinanza. Condividere il patrimonio culturale per promuovere la partecipazione e la formazione civica, Torino 2005.

Mairesse, F., The Term Museum, v: What is a museum? (ur. Davis, A., Mairesse, F., Desvaleés, A.), München 2010, str. 19-58.

Maroević, I., Uloga muzealnosti u zaštiti memorije, v: Maroević, I., Baštinom u svijet Muzeološke teme - Zaštita spomenika. Arhitektura, Petrinja 2004 (izvirna objava 1997), str. 42-46.

Maroević, I., The museum message: between the document and information, v: Museum, Media, Message (ur. Hooper-Greenhill, E.), London, New York 1999, str. 24-36.

Maroević, I., Što prezentiramo u muzeju - predmete ili ideje?, v: Baštinom u svijet. Muzeološke teme - Zaštita spomenika. Arhitektura, Petrinja 2004 (izvirna objava 2002), str. 58-62.

Maroević, I., Towards the New Definition of Museum, v: What is a museum? (ur. Davis, A., Mairesse, F., Desvaleés, A.), München 2010, str. 140-149.

Marstine, J., The contingent nature of the new museum ethics, v: The Routledge Companion to Museum Ethics (ur. Marstine, J.), London 2011, str. 3-25.

Perko, V., Muzeologija. Arheologija za javnost. Muzej Krasa, Ljubljana 2014.

Sandell, R., Museums as agents of social inclusion, Journal of Museum menagement and Curatorship 17/4, 1998, str. 401-418.

Sandell, R., On ethics, activism and human rights, v: The Routledge Companion to Museum Ethics (ur. Marstine, J.), London 2011, str. 129-145.

Scheiner, T., Defining Museum and Museology: An Ongoing Process, v: What is a museum? (ur. Davis, A., Mairesse, F., Desvaleés, A.), München 2010, str. 93-105.

Smith, L., Uses of Heritage, London, New York 2006.

Šola, T., Eseji o muzejima i njihovoj teoriji. Prema kibernetičkom muzeju, Zagreb 2003.

Šola, T., The Museum Definition, v: What is a museum? (ur. Davis, A., Mairesse, F., Desvaleés, A.), München 2010, str. 106-112. 
Verena Perko

\section{Migracije, družbeno angažirana muzejska tema, in zakaj se ji slovenski muzeji uspešno izogibajo?}

Ključne besede: migracije, begunska kriza, muzeji, postmuzeji, muzeologija

Begunska kriza se je v zadnjem letu dni spremenila v človeško tragedijo, ki po mnogočem spominja na čas druge svetovne vojne. Sredozemsko morje, opevani mare nostrum, je postalo grozljiva skupna grobnica brezštevilnih. Posledica vojne pa so tudi uničevanja zgodovinskih mestnih središč, spomenikov in druge kulturne dediščine na t. i. kriznih območjih, ki so dosegla nedoumljive razsežnosti. Muzeji po svetu so se aktivno odzvali na družbene potrebe. Cilj je bil sodobno družbo pozvati k razmisleku in odprtemu dialogu ter ublažiti strah pred neznanim in zmanjšati plimo sovraštva, preden doseže vseuničujočo razsežnost. Z begunsko krizo se je meddružbeni dialog pokazal kot nuja in ultimativni imperativ, nekaj, brez česar družbe prihodnosti ni več mogoče zagotoviti. Muzejem je sodobna družba namenila vlogo verodostojnega medija za komunikacijo dediščinskih vsebin. $Z$ rabo metaforičnega in metonimičnega opredmetenega »jezika« imajo izjemno veliko družbeno moč ter predstavljajo most med znanostjo in sodobno družbo, med družbami preteklosti in sedanjosti, med elitami in obrobjem. Reformatorji muzejev iz druge polovice 20. stoletja so menili, da tradicionalni muzeji kljub reorganizacijam ne morejo streči potrebam sodobne družbe. To je bil vzrok nastanka nove muzeologije, ki muzej razume kot družbeno odgovorno ustanovo. Opremlja jo s specifičnimi teoretskimi znanji, ki omogočajo spreminjanje dediščine $\mathrm{v}$ družbeno relevantno komunikacijo neverbalnega značaja. Članek, njegova teoretska vsebina, argumentira sodobne koncepte muzeja in z njimi presoja družbeno odgovornost v delovanju slovenskih muzejev. Sodobni muzeji ali postmuzeji so ustanove $z$ aktivnimi družbenimi nalogami. Angažiran način prinaša družbeno odgovornost in nevarnost "političnega zdrsa«. Nasprotno pa "znanstvena objektivnost « in "apolitičnost « zagotavljata družbeno sinekuro. Vendar ustanove, ki se vzdržujejo $\mathrm{z}$ davkoplačevalskim denarjem, niso politično nevtralne in s svojo politično korektnostjo dejansko skupnosti odtujujejo sodobna "orodja“ demokratizacije in hromijo njen razvoj. Stanje družbene ohromelosti, kakršna se je izostrila v času begunske krize, ustreza slovenski družbi, ki se ne želi soočiti s svojo pravo podobo. Govoriti o begunski krizi pomeni posredno izpostavljati trpljenje ljudi na begu ter pokazati na krivdo vseh nas; pomeni vtikati prst v najgloblje in najsramotnejše rane Evrope; pomeni prevzemati družbeno in osebno odgovornost. To vključujejo tudi sodobni koncepti muzeja. 


\section{Verena Perko}

\section{Migration, Socially Engaged Museum Theme, and Why Slovenian Museums Successfully Avoid it?}

Keywords: migrations, refugee crisis, museums, post-museums, museology

In the last year, the refugee crisis has turned into a human tragedy, in many ways resembling that of World War Two. The Mediterranean Sea, the highly praised Mare Nostrum, has become a horrifying collective tomb for countless people. Another consequence of war is also the destruction of historical urban centres, monuments, and other cultural heritage in so-called crisis areas - a destruction which has reached unfathomable proportions. Museums all across the world have actively responded to society's needs. Their goal has been to encourage an open dialogue in our society, as well as alleviate fear of the unknown, and reduce the tide of hatred before it reaches world-shattering proportions. During the refugee crisis, it has become apparent that an intersocietal dialogue is both a necessity and a definitive imperative; without it, the society of the future cannot possibly be assured. Modern society has given museums the role of being a credible medium with a mission to communicate heritage contents. By using a metaphorical and metonymic language museums have an extraordinary social power and represent a bridge between science and modern society, between societies of the past and present, between the elites and marginal groups. The museum reformers of the second half of the $20^{\text {th }}$ century were of the opinion that, despite many reorganizations, museums cannot serve the needs of modern society. This was the reason a new museology emerged that substantiates museums as a socially responsible institution. It equips that institution with specific theoretical knowledge that enables the conversion of heritage into a socially relevant communication of a nonverbal nature. The article theoretically argues for modern museum concepts and, using them, contemplates social responsibility in the inner workings of Slovenian museums. Contemporary museums or post-museums are institutions that carry out active social tasks. An engaged manner brings along social responsibility and the danger of a "political slide". On the other hand, "scientific objectivity" and "apoliticalness" ensure that they become a social sinecure. However, since these institutions are maintained with taxpayers' money, they are not politically neutral and are actually alienating modern "tools" of democratisation from the community through their political correctness, thereby impeding its development. This state of social paralysis, which came into focus during the refugee crisis, fits well into a Slovenian society that does not want to face its true appearance. To speak of the refugee crisis means indirectly 
exposing the suffering of people in flight and placing blame on all of us; it means poking our fingers into the deepest and most shameful wounds of Europe. It means taking social and personal responsibility - which is also included in the concept of a modern museum. 